\title{
Turkish D-light: accentuating heritage values with daylight
}

1 Sura Al-Maiyah PhD, CIBSE, SLL, ICOMOS

Senior Lecturer, Portsmouth School of Architecture, University of Portsmouth, Portsmouth, UK
2 Hisham Elkadi PhD, FRICS, FAIB, ARIBA

Head of School, School of Built Environment, University of Salford Salford, UK
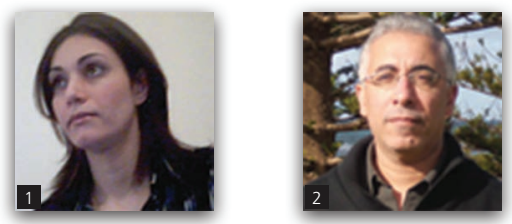

Historic buildings have their own cultural identity, which is often related to their aesthetic qualities such as period characteristics (geometry, size, colour, form and shape), materials and construction. Daylight is one of the primary elements contributing to the distinctiveness of the visual environment of many historic buildings, but is rarely considered as one of the components that shape the character of a building when adaptive preservation schemes of historical buildings are planned. Many historic buildings were originally designed to accommodate activities different to their new use and preserving the quality of daylight that originally contributed to their visual identity is a challenging task. Maintaining the 'day-lit appearance' of a building can be particularly problematic if the building is to be used as a museum or a gallery owing to the artefacts' conservation requirements. This work investigated the opportunities of maintaining the original ambient conditions of renovated historical buildings while meeting the required daylight levels of the proposed new use. The study utilised an annual daylight simulation method and hourly weather data to preserve daylight conditions in renovated historic buildings. The model was piloted in a Turkish bathhouse situated in Bursa, Turkey, that is currently under renovation. The simulation model produces $\mathbf{4 4 8 3}$ hourly values of daylight illuminance for a period of a whole year using the computer program Radiance. It is concluded that daylight characteristics should be taken into account when developing a renovation scheme. With increasing pressure on valuing historic buildings in many parts of the world, the work reported here should be beneficial to those concerned with the conservation and adaptive reuse of historic buildings. The study findings could also be useful to those interested in predicting potential energy savings by combining daylighting and electric lighting in historic buildings.

\section{Introduction}

Several urban rehabilitation projects have recently been implemented in Bursa, Turkey's fourth largest city. A number of the city's indigenous buildings have been converted to museums, art galleries, cultural venues and community centres. Maintaining and reusing historic buildings - a practice well-supported by the Turkish government - is often seen as a way not only to preserve the physical building fabric 'as a tangible link with the past' but also as an opportunity to preserve the intangible heritage of traditional skills and craftsmanship (Cengiz, 2012). Often, the intention is to provide new accommodation for the storage and exhibition of valuable artefacts. Many historical buildings were originally designed to accommodate different activities to their new use. Preserving the quality of daylight that originally contributed to their visual identity can be a very challenging task. Furthermore, as most historical buildings were originally designed to maximise daylight, maintaining the 'day-lit appearance' of a building can be problematic in terms of artefact conservation requirements. On the other hand, successful utilisation of daylight can create a better visitor experience and museum environment as well as improve the energy efficiency of a building. In top-lit galleries (in temperate climates), savings in installed lighting loads of the order of 50-60\% have been estimated if daylight is properly integrated with artificial lighting (Carver, 1994).

Museums and art galleries are well recognised for their demanding day/lighting criteria (Kim and Chung, 2011). Museum personnel often face the challenge of illuminating the museum environment while addressing the conservation requirements of museum objects (de Hoyo-Meléndeza et al., 2011). Whereas retrofitting ordinary non-historic old buildings can offer a number of possibilities for improving the ambient conditions and energy efficiency of buildings (Baker and Steemers, 2002), in a heritage building, a radical change to the original quality of daylight through extensive use of artificial light or displacement of daylight can have a critical impact on the 
visual character and sense of place (Al-Maiyah and Elkadi, 2007). Although conservation practice in general is clear about the importance of applying and adopting 'minimal intervention' when developing a rehabilitation scheme, the practice of implementing minimal intervention is often understood by designers in terms of preserving the tangible aspects of a building. Indeed, preserving the original tangible components of buildings such as their materials, fabric and fenestration features is key to preserving the physicality of buildings. There are, however, many other facets of historic buildings that contribute to their distinctive quality and significance.

Daylight is one of the intangible elements that contributes to the distinctiveness of many historical buildings and settlements (Al-Maiyah and Elkadi, 2012). However, when initiating preservation schemes of historical buildings, daylight is rarely considered as one of the components that shape the building's character. A review of relevant documents suggests that at present there is no clear recognition of the role of daylight in shaping the visual character of historical buildings. For example, in the US government's official text on preserving old buildings, Nelson (2004: p. 171) identifies the visual aspects and physical features that comprise the appearance of historical buildings as follows: 'Character-defining elements include the overall shape of the buildings, its materials, craftsmanship, decorative details, interior spaces and features, as well as the various aspects of its site and environment'. Although the environment, as evident in this quote, has been identified among the various components that give a building its visual character, the actual description does not provide an explanation of what this term means in relation to the building context, whether it is the surrounding external context or internal ambient conditions. The work is mainly limited to identifying tangible aspects related to the physical characteristics of buildings. Without a clear valuation and an understanding of the value of daylight in shaping the visual character of a historical building, it would be rather challenging to first establish whether daylight should be taken into account when developing a renovation scheme, and then what might be considered 'minimal intervention' in terms of preserving its ambient conditions.

This paper highlights the importance of daylight in accentuating the distinctiveness of heritage buildings. The pressure on city councils to provide new uses for large numbers of empty heritage buildings could result in distorted renovation projects. Appropriate analysis of daylight would ensure the continuing celebration of heritage in context as well as improving energy efficiency measures.

\section{Daylighting regulations and practice in Turkey}

The role of daylight in improving the energy efficiency in buildings has recently received much attention in energy performance regulations in Turkey. The value of daylight and the importance of maximising its effectiveness for illuminating building interiors, which were clearly stated in building performance legislations introduced in 2008, have been further emphasised recently with the latest introduction of the new Turkish lighting standard.
As a candidate country for European Union membership, Turkey adopted the European standard for lighting in work places (EN 12464-1:2011) (BSI, 2011) in January 2012 as the Turkish lighting standard (TS EN 12464-1:2011). Item 4.10 of this standard emphasises the role of daylight provision in buildings and provides, in clause 5.4, lighting requirements for retail premises such as restaurants and hotels, theatres and concert halls, as well as exhibition halls and museums. These requirements can also guide the reuse of historical buildings. However, while recommended light levels for most of these public premises are given in the European guidelines, there are no values given for museums, where lighting requirements are mainly determined by the display classification. However, other reliable international guidelines such as those recommended by the Illuminating Engineering Society of North America (IESNA) or the Charted Institution of Building Services Engineers (CIBSE) can be used (and have often been used in previous similar studies) to establish lighting requirements in a museum or gallery environment.

As well as the Turkish-adopted European standard, there are currently two other pieces of legislation in Turkey that include guidelines on building lighting - legislation for the effective use of energy sources and energy consumption and legislation of energy performance in buildings, both dating back to 2008 (Erkin et al., 2009). However, neither provides recommendations for lighting levels or illuminance values. With the new lighting standard now in place, there is an even better ground or base to measure how traditional buildings perform against recent requirements. As the renovation and reuse of old buildings is a well-received practice and is increasingly emerging in many other major cities in Turkey, the work reported here should be beneficial for those concerned with conservation practice and the reuse of historical buildings in the region.

\section{Daylighting requirements in museum buildings}

While the presence of natural light with its vibrant qualities is an attractive design feature in many building types, in a day-lit museum environment, certain preventive measures have to be taken to minimise its 'deleterious' effects on museum collections. Daylight has the most desirable colour-rendering qualities for aesthetic reasons, which are important to a museum's function. However, the high energy in the ultraviolet region of the spectrum can cause chemical and physical damage to fragile objects in collections such as discolouration, fading, yellowing and surface cracking. Unnecessary visual light can also pose a threat to certain types of museum objects. The 'reciprocity law' states that the cumulative photochemical effect 'is directly proportional to the illumination levels multiplied by the time of exposure' (US DoI, 1999). Thus, an exposure of $200 \mathrm{~lx}$ for 6 months can cause as much damage as $100 \mathrm{~lx}$ exposure over 1 year. Reducing exposure time is therefore another important measure to limit damage from light. On the other hand, the rate and extent of deterioration brought about by the amount of light and exposure time varies between the different types of objects depending on their material properties and chemical composition. 
In general, museum artefacts can be grouped into three categories based on sensitivity to light - highly sensitive objects derived from organic origins, partially sensitive objects containing organic and inorganic substances, and insensitive objects having geological origin. IESNA established illuminance recommendations and annual exposure times for the various material-type categories found in a museum collection (Rea, 2000). As illustrated in Table 1, a maximum of $50 \mathrm{~lx}$ is recommend for highly sensitive objects and $200 \mathrm{~lx}$ and $300 \mathrm{~lx}$ for partially sensitive and insensitive objects, respectively. Similar illuminance values are also given in the CIBSE lighting guide (CIBSE, 1994). In terms of exposure time, the values given in the IESNA guidelines are lower than those given in the CIBSE lighting guide (Table 1); the latter values are based on the assumption that the lights will be either extinguished or maintained at a very low level outside museum opening hours. While reducing the length of exposure to light is important in terms of conservation considerations, determining the correct level of illuminance in display spaces is equally important in terms of comfort and visibility. The limits recommended in Table 1 are widely accepted as practical for reducing damage while maintaining adequate viewing conditions (CIBSE, 1994) and were thus adopted in the present study for assessing annual illuminance values and total annual exposure to daylight in the selected case study.

\section{Methodology}

Several site visits to selected heritage buildings (buildings recently converted to museums or to be converted to museums) in Bursa were conducted in May and August 2012 and September 2013 (Figure 1). The selected buildings included Demirçi bathhouse (a small bathhouse currently under renovation), Uluumay Museum (an old religious school that became a museum in 2000) and Ordekli bathhouse (converted to an art and cultural centre in 2008). The Muradiye Madrasa (an old school) is also soon to be converted into a museum. The planned use of Demirçi bathhouse is a cultural centre where art exhibitions will be held regularly to benefit the village community. The building therefore offers an opportunity to test the possible use of its original ambient daylight conditions for a better adaptive reuse strategy.

Until recently, daylight studies of buildings have mainly focused on assessing the illuminance values received into a building or part of a building on selected seasonal dates and times of day. Key seasonal dates that are often used for performing such analyses are the winter and summer solstices and the fall and spring equinoxes. Since the early 2000s, an increasing number of authors have argued the limitation of such an approach and advocated a more realistic systematic approach of evaluation, preferably hourly annual evaluation (de Hoyo-Meléndeza et al., 2011; Mardaljevic, 2000, 2006; Mardaljevic et al., 2011).

The revised methodology using annual evaluation of daylight illuminance levels is essential in daylight studies of museums and exhibition buildings given the sensitivity of artworks and other objects to excessive exposure to illuminance levels. Since natural illuminance values are mainly affected (among other things) by sky conditions and the thickness of the sky cover, it is important to separate the various sky conditions and choose the right sky type for each step/hour of the evaluation. For this reason, Bursa sky conditions were classified into three types using hourly cloud cover data obtained from a standard weather file for the city (Ashrae IWEC weather file for Bursa) - clear sky (less than 30\% cloud cover), partly cloudy sky (cloud cover of 30-70\%) and overcast (more than $70 \%$ cloud cover). This classification of sky types is in line with the CIE definitions of standard general sky models and use of this hourly statistical based approach (Kensek and Yong Suk, 2011; Lighting Design and Simulation Knowledgebase, 2015) is similar to previous work reported by Tzempelikos and Athienitis (2005). Hourly daylight simulations for a period of 1 year were performed to calculate annual illuminance values received into the
Maximum illuminance: Ix

\section{CIBSE}

Subject to heating and

Objects insensitive to light (e.g. metal, stone, glass, ceramics and most minerals) adaptation effects Objects moderately sensitive to light (e.g. textiles 200 with stable dyes, oil and tempera paintings, ivory and wood)

Objects highly sensitive to light (e.g. textiles, 50 costumes, tapestries, prints and drawings, silk and writing inks)

Table 1. Maximum illuminance levels and accumulative exposure values given in the IESNA lighting handbook (Rea, 2000) and the CIBSE lighting guide (CIBSE, 1994) for various types of exhibits
Maximum annual cumulative exposure: Ixh

IESNA

CIBSE

IESNA
Depends on exhibition situation; max $300 \mathrm{~lx}$ 200

50
Depends on exhibition situation $600000 \quad 480000$ 480000
150000

50000 


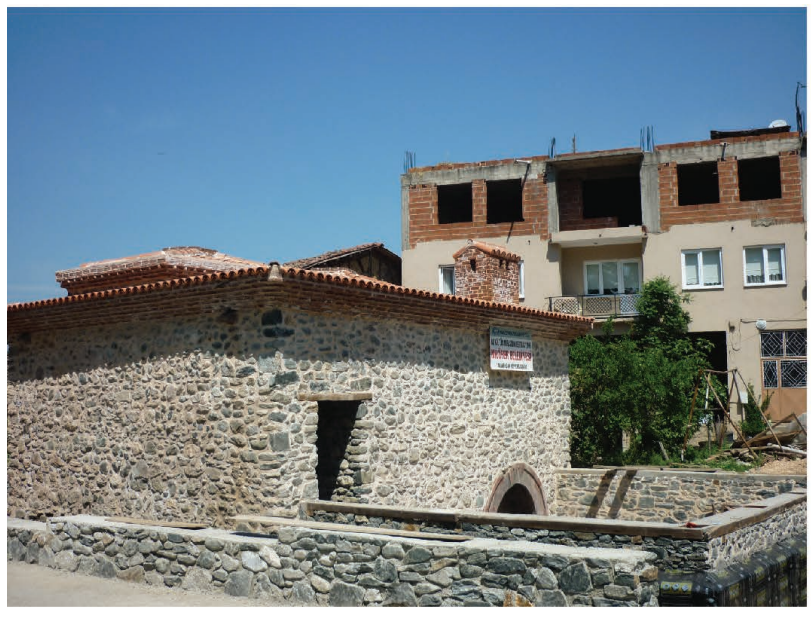

(a)

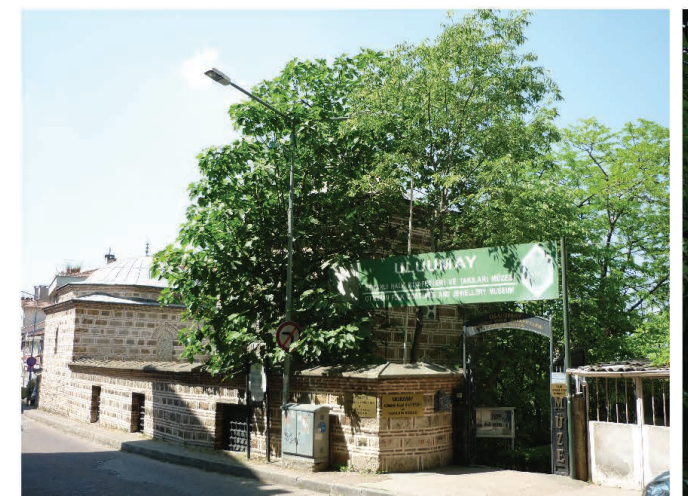

(d)

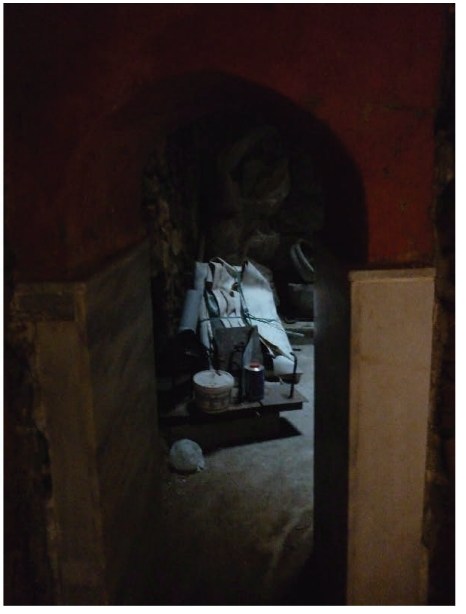

(b)

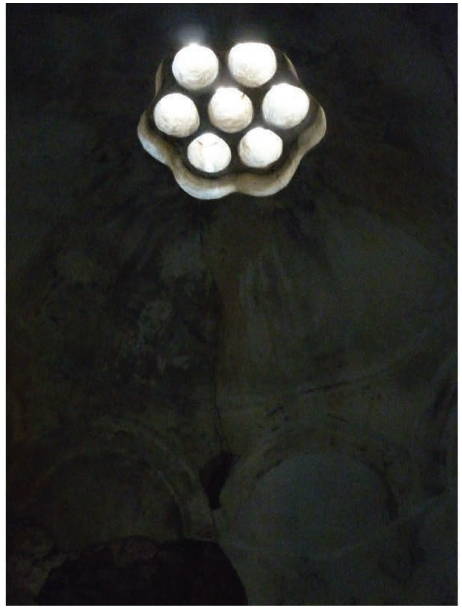

(c)

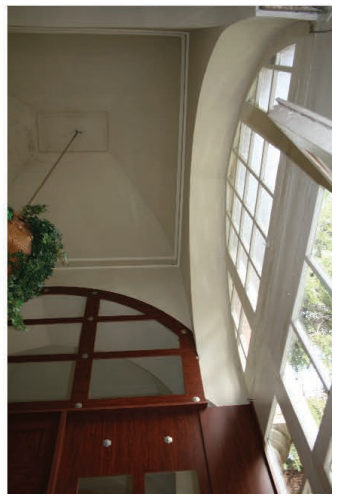

(f)

Figure 1. Demirçi bathhouse with internal views of the hammam showing the top-lit dome of the studied northern hot room ((a)-(c)), Uluumay Museum (d) and Muradiye Madrasa ((e) and (f))

selected bathhouse using existing CIE models for clear, overcast and intermediate sky conditions in the Integrated Environmental Solutions (IES) Virtual Environment Radiance.

Bursa is located in north-western Anatolia within the Marmara region between $40^{\circ} 11^{\prime} \mathrm{N}$ latitude and $29^{\circ} 03^{\prime} \mathrm{E}$ longitude. The city has a Mediterranean climate with dry hot summers and an average of $14 \mathrm{~h}$ of daylight and mild winters with an average of $9 \mathrm{~h}$ of daylight. However, classification of the sky conditions using the cloud cover data mentioned earlier reveals a total of $1945 \mathrm{~h}$ of clear sky conditions in Bursa, $1362 \mathrm{~h}$ of mixed sky conditions and $1322 \mathrm{~h}$ of overcast conditions during daylight hours per year. An illustration of the average annual direct normal illuminance received by the city in units of lux hours (lx h) according to the weather file used in the study is shown in Figure 2. As illustrated in the figure, the amount of direct normal illuminance received by the city from the solar disc over the summer period (June to September) can be as high as $39000 \mathrm{lxh}$. Thus, rehabilitation projects (in the region) that seek to recycle historical buildings to re-function as museums should take advantage of the availability of such high levels of illuminance while controlling its contribution to the overall visual environment of the buildings.

Radiance is well known as a powerful and highly accurate modelling tool. Several previous studies with similar content to this work have used Radiance to assess daylight levels and visual comfort criteria in reused historical buildings. Al-Sallal and Dalmouk (2011), for example, used Radiance in an evaluation of the daylighting performance of one of the traditional residential buildings in the United Arab Emirates that was converted to a museum. Daylight levels and ambient conditions in the present town hall in Florence (Palazzo Vecchio), where some of the most precious and ancient tapestries are exhibited, were also examined using the Radiance modelling tool (Balocco and Frangioni, 2010). A three-dimensional digital model of the bathhouse was therefore developed using the geometry model creator (Model IT) in the IES Virtual Environment and the daylight simulation package Radiance was used to perform the annual illuminance evaluation. Reflectance values used for the internal walls and the ceiling (including the domes) were 50\% and $70 \%$, respectively; a reflectance of $20 \%$ was used for the 


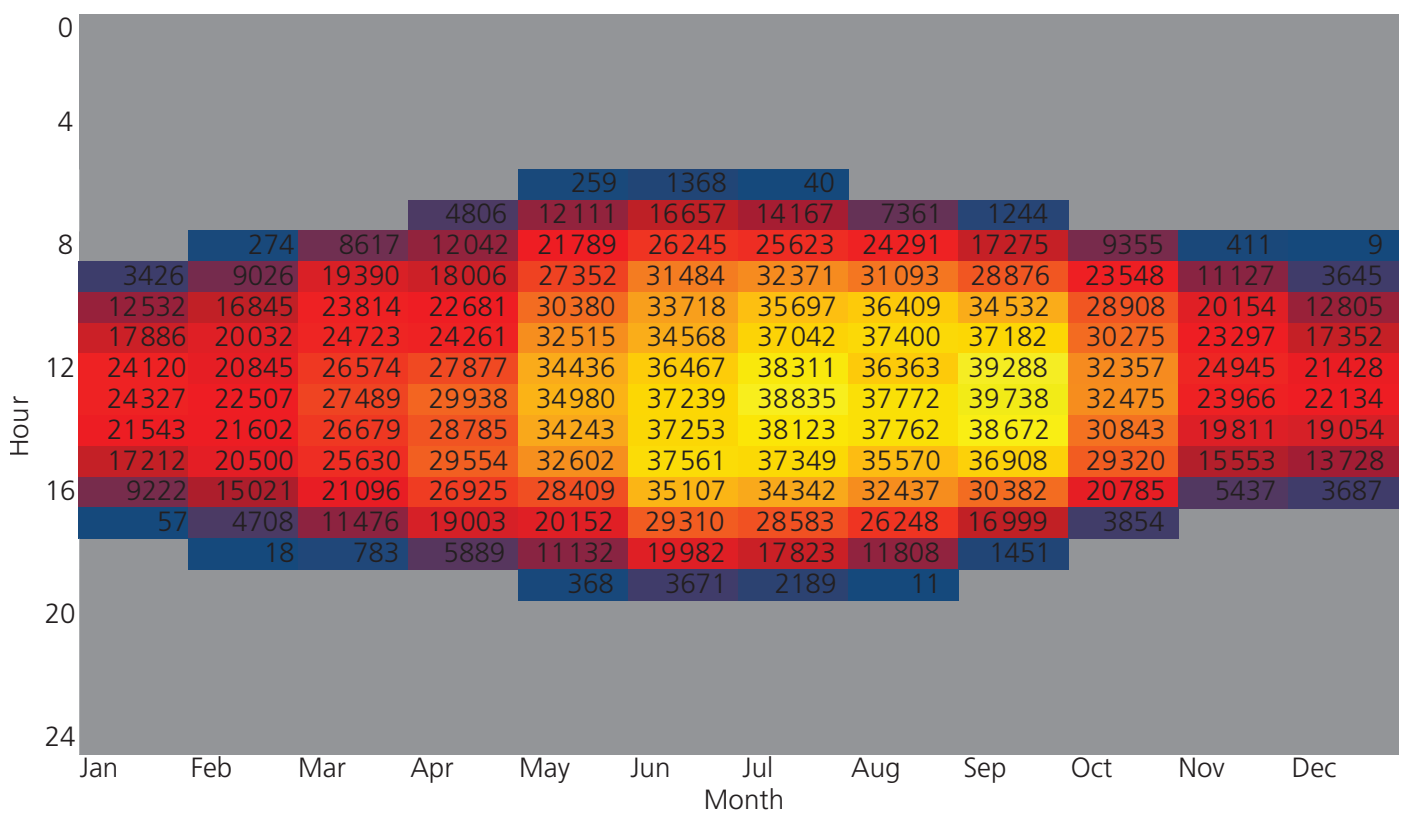

Figure 2. Annual direct normal illuminance received in Bursa in units of lux hours

floor. These figures were established based on a description of the original surface finishes identified in the restoration report that was submitted by the team for planning permission.

In many building types (e.g. office buildings and schools), daylight studies are usually performed by calculating the horizontal illuminance values on the work plane where most of the visual tasks take place. By contrast, in exhibition halls, where some artwork can only be mounted on the walls either vertically or horizontally, evaluating the distribution of daylight on the vertical surfaces of a room is as important as evaluating the values of work plane illuminance. For this reason, an internal view with a fixed camera position that shows the various zones illuminated with daylight within a selected room in the bathhouse was chosen for the evaluation (Figure 3). A series of reference points assembled on five main axes on the south-, north- and west-facing walls of the room was then used to predict the hourly values and the total exposure to illuminance during daylight hours ( 5 a.m. to 7 p.m. in summer and 8 a.m. to 4 p.m. in winter). The points were situated on sections of walls likely to be used for exhibiting artworks at three different heights: $0.70 \mathrm{~m}$ (point c), $1.45 \mathrm{~m}$ (point b) and $2.2 \mathrm{~m}$ (point a) above the floor. The simulation model produced 4483 illuminance values for every calculation point.

\section{Case study building: Demirçi bathhouse}

The plan of Demirçi bathhouse (or hammam) follows the traditional layout of Roman baths, with a cold room, a semi-hot room and a hot area (Figure 4). The cold room, known as the frigidarium, is usually

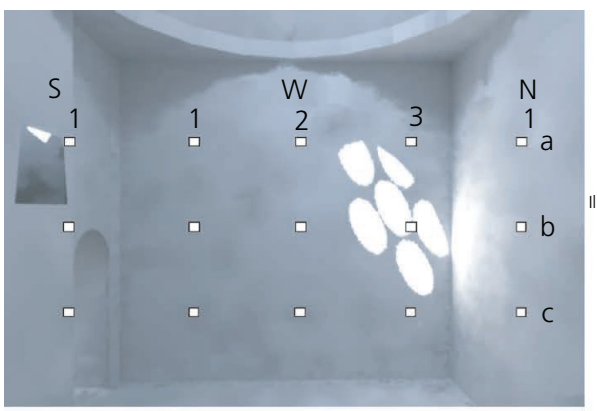

(a)

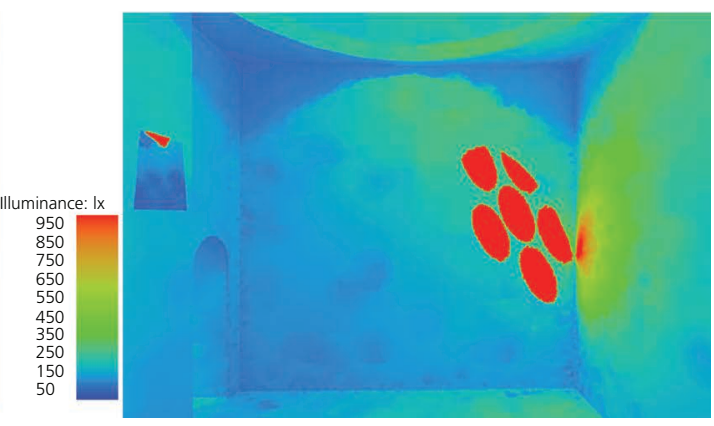

(b)

Figure 3. (a) Location of the digital sensors used in the analysis. The sensors were placed where objects are likely to be mounted at different heights: $0.70 \mathrm{~m}$ (point c), $1.45 \mathrm{~m}$ (point b) and $2.2 \mathrm{~m}$ (point a) above the floor. (b) Work plane illuminance 


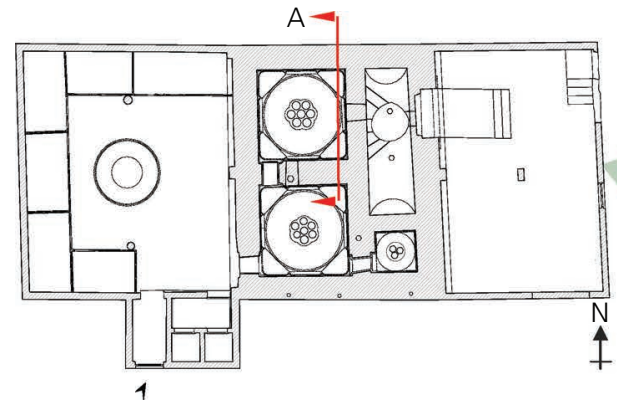

(a)

Figure 4. (a) Plan of the hammam showing the heated area in the middle and the cold and warm areas on the west side on the building; the cross-section line $A$ indicates the position of the

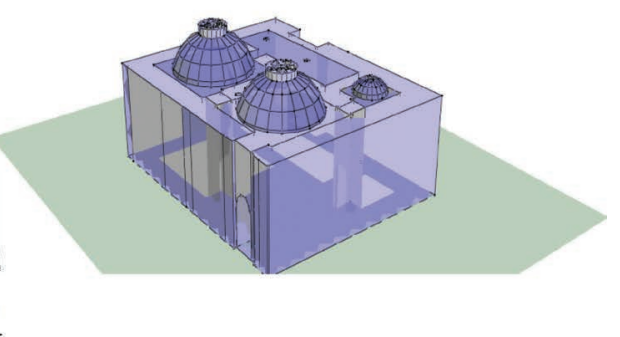

(b) section of the hammam

Analysis of daylight levels on the three walls shows the possibility of maintaining acceptable levels of daylight within the safety levels $(480000 \mathrm{lxh})$ for moderately sensitive exhibits such as oil paintings, frescos, ivory and wood. A further in-depth investigation revealed particular times at particular points on the walls when precautions need to be taken. While the overall cumulative illuminance falls within the accepted range, contact with illuminance that exceeds maximum exposure levels $(200 \mathrm{~lx})$ at any particular time could cause serious damage to exhibits.

All points on the south wall appear to receive acceptable levels of illuminance exposure all year around. The average monthly illuminance remains under $140 \mathrm{~lx}$ (Figure 6). Similarly, the accumulative levels similarly fall well within the $480000 \mathrm{~lx}$ h limit all year around (Figure 7). As shown in Table 2, the accumulative illuminance values received by the upper section of the wall, the centre section and its lower area range between $\approx 456000 \mathrm{~lx} \mathrm{~h}$ and $\approx 350000 \mathrm{~lx} \mathrm{~h}$.

The north-facing wall receives a maximum monthly average illuminance of $220 \mathrm{~lx}$ in its upper part (1a) during April (Figure 8). The upper part of the wall seems to be the only section that would require attention during April and August if sensitive objects are to be exhibited. Similar results were also obtained for the accumulative illuminance. The presence of direct normal illuminance at this particular point and time of the year can be as high as $80000 \mathrm{~lx}$, resulting in accumulative values well above the safety limits recommended for moderately sensitive objects. Precautions are therefore to be taken to avoid exhibits placed on the upper and middle sections of the wall during August (Table 2). Showcases equipped with ultraviolet protective coatings can add another level of safety in spots where there might be a concern about the level of daylight.

The west-facing wall is a long running wall that would provide a convenient surface for the exhibition of artefacts. For testing purposes, this wall was therefore divided into three parts (left-hand, centre and right-hand sections). Analysis of the left-hand side of 

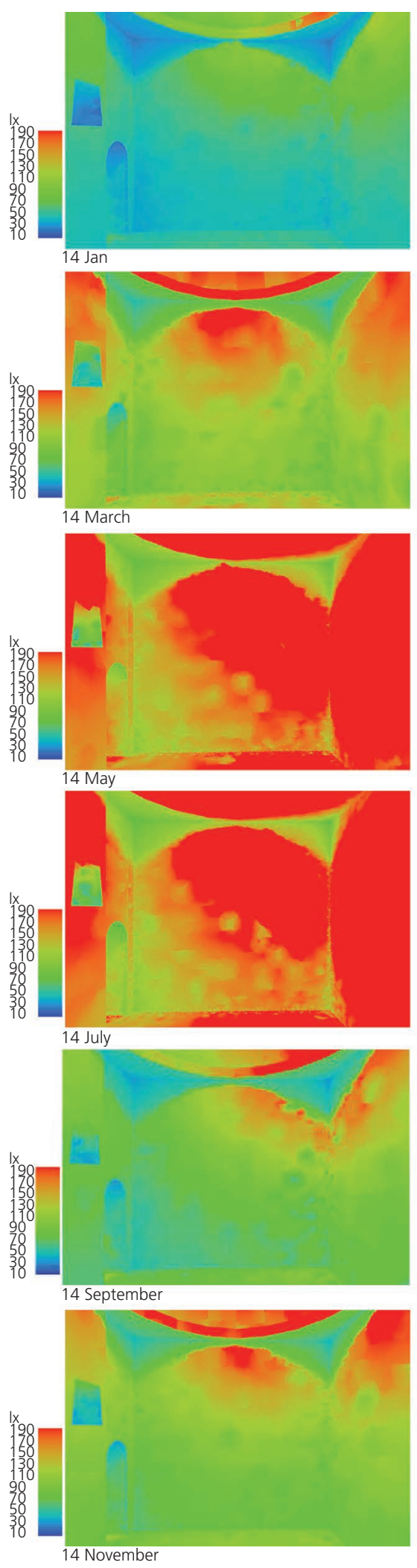

Figure 5. Interior views of the studied northern hot room showing the seasonal variation in daylight levels at 10.00 a.m. on a specific day (the 14th of every month) throughout the year. The scale bar
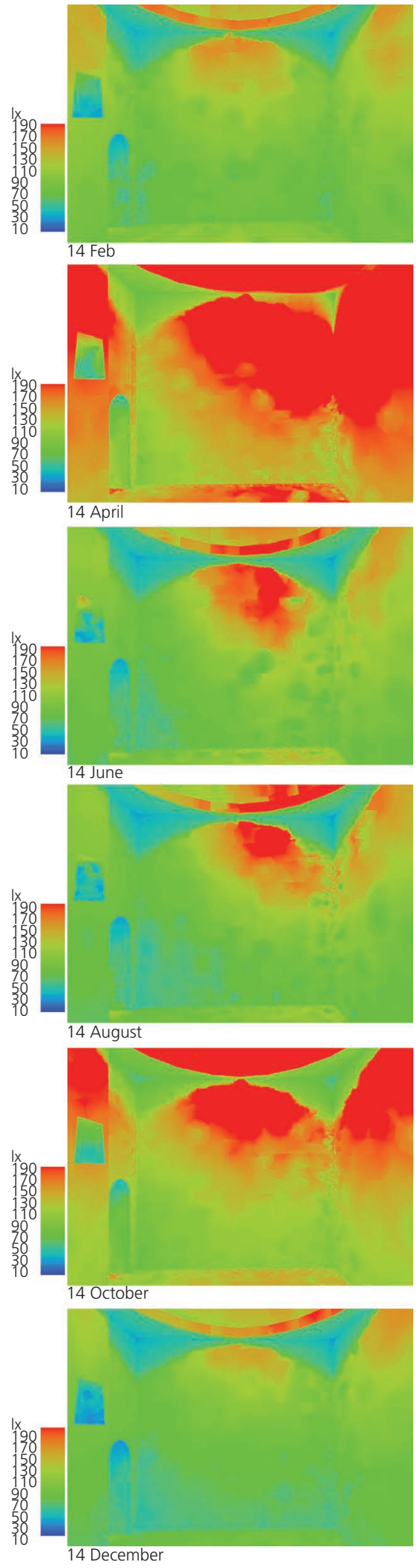

on the left-hand side of each false-colour rendering was fixed between 0 and $200 \mathrm{~lx}$ in order to illustrate the difference in illuminance values 


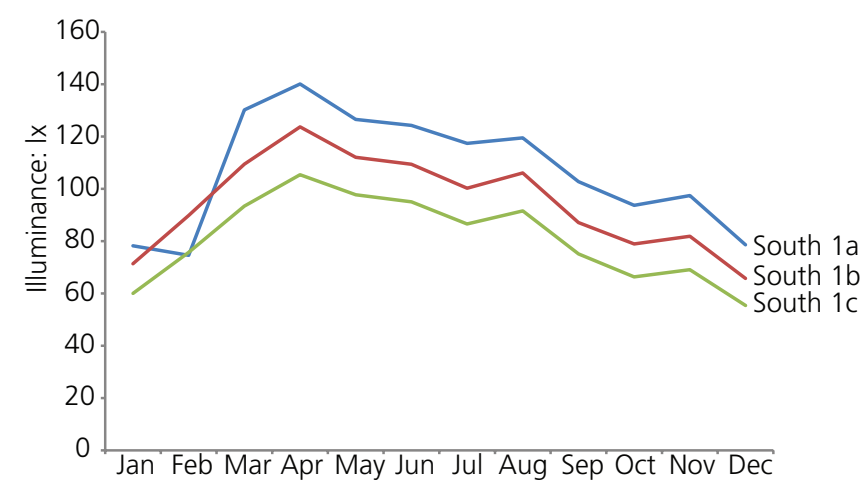

Figure 6. Average monthly illuminance on the three sections of the southern wall

the west-facing wall shows no reason for concern (Figure 9). The maximum monthly average was again mostly under $120 \mathrm{~lx}$ except for a slight increase during April in the upper part of the wall where the average value predicted was $135 \mathrm{~lx}$ (Figure 10). The annual accumulative exposures were also under the $480000 \mathrm{lxh}$ limit, allowing for unconstrained usage of the wall for the exhibition of moderately sensitive materials (Table 2). Similarly, the centre part of the west-facing wall shows higher illuminance levels during the summer period, particularly 25 May to 25 June, on the upper part of this section (Figure 11). The right-hand side of the west-facing wall however has much higher levels of illuminance for the middle part of the wall for a longer period of the year (May to August).

On a monthly basis, the central section of the three selected walls of the room (point $\mathrm{b}$, located at $1.45 \mathrm{~m}$ height) seems to receive an average illuminance of $60-90 \mathrm{~lx}$ between September and February and about 110-130 lx between March and August. These figures fall well within the 50-200 lx comfort criteria range set by CIBSE and IESNA stated earlier. However, if the upper limit of the range is to be met, the maximum intensity of additional lighting needed to compensate for the lack in daylight is $140 \mathrm{~lx}$ in winter (December to January) and about 70-110 lx for the rest of the year. This additional lighting could be provided as part of the design of display containers and should thus be carefully adjusted depending on the season in order to prevent dramatic changes to the ambiance of the space. As much as blocking access to daylight can affect the visual perception of a room (as noted during a site visit to Uluumay Museum where daylight openings were fully blocked and replaced by artificial lighting), adding unnecessary artificial lighting can similarly alter the ambient conditions of a place and thus its visual perception. Carefully integrating daylight and artificial lighting can thus not only assist in preserving art objects and maintaining the original lighting conditions of a heritage building but can also contribute to improve its energy efficiency. A reduction in the use of artificial electric lighting would provide savings in energy bills. The current practice of entirely blocking daylight in order to protect museum artefacts not only modifies the ambience of heritage buildings but also increases energy costs.

\section{Conclusions}

Daylight is a key ingredient in maintaining the identity of cultural built heritage. In Bursa, interventions to adapt historical buildings to more contemporary use are essential for their sustainability. Such interventions, however, cannot just rely on the new Turkish lighting standards, particularly where museums are intended as the new functions for these buildings.

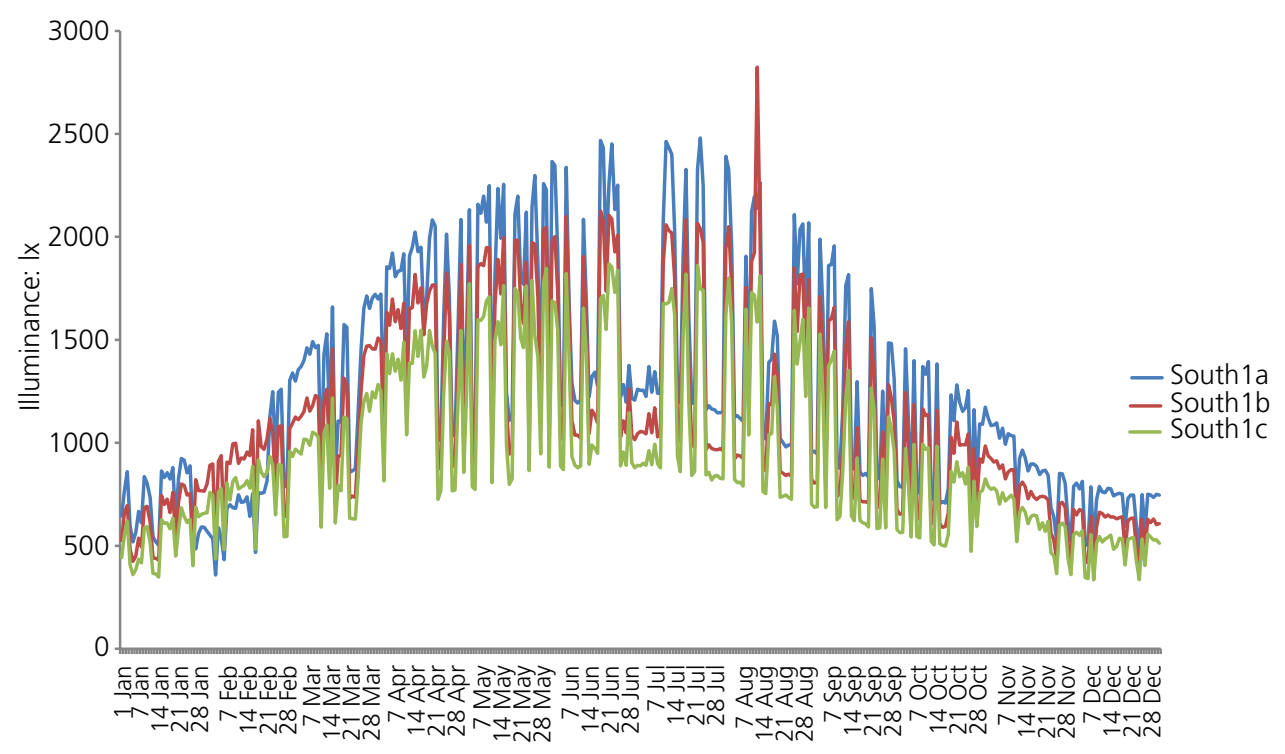

Figure 7. Daily total illuminance on the southern wall between

1 January and 31 December 


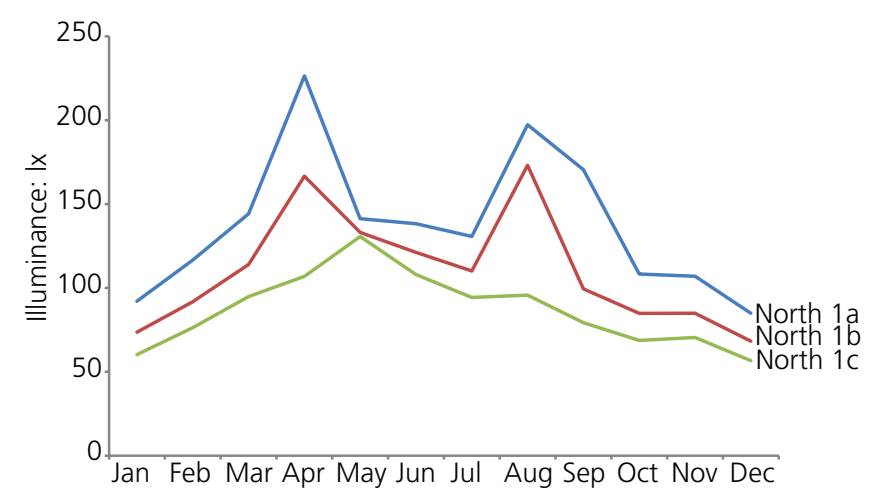

Figure 8. Average monthly illuminance on three sections of the northern wall
The current study shows that a thorough evaluation of seasonal variations in daylight and hence careful distribution of artefacts in a heritage building not only maintains its ambience and character but also assists in protecting exhibited objects from damage due to excessive exposure to daylight. The outcomes of the simulation of Demirçi hammam highlight the importance of yearly daylight measurements rather than analysis on the basis of data from sample dates. The particular structure of this building, together with daylight access through the dome structure, necessitates accurate investigation of the dynamic profile of daylight across various wall surfaces. The results also clearly show the possibility of using daylight across many walls of the building to exhibit sensitive objects and artefacts. The results can be used to maintain the ambience and original experience of the building despite the strict light requirements of its intended new use.

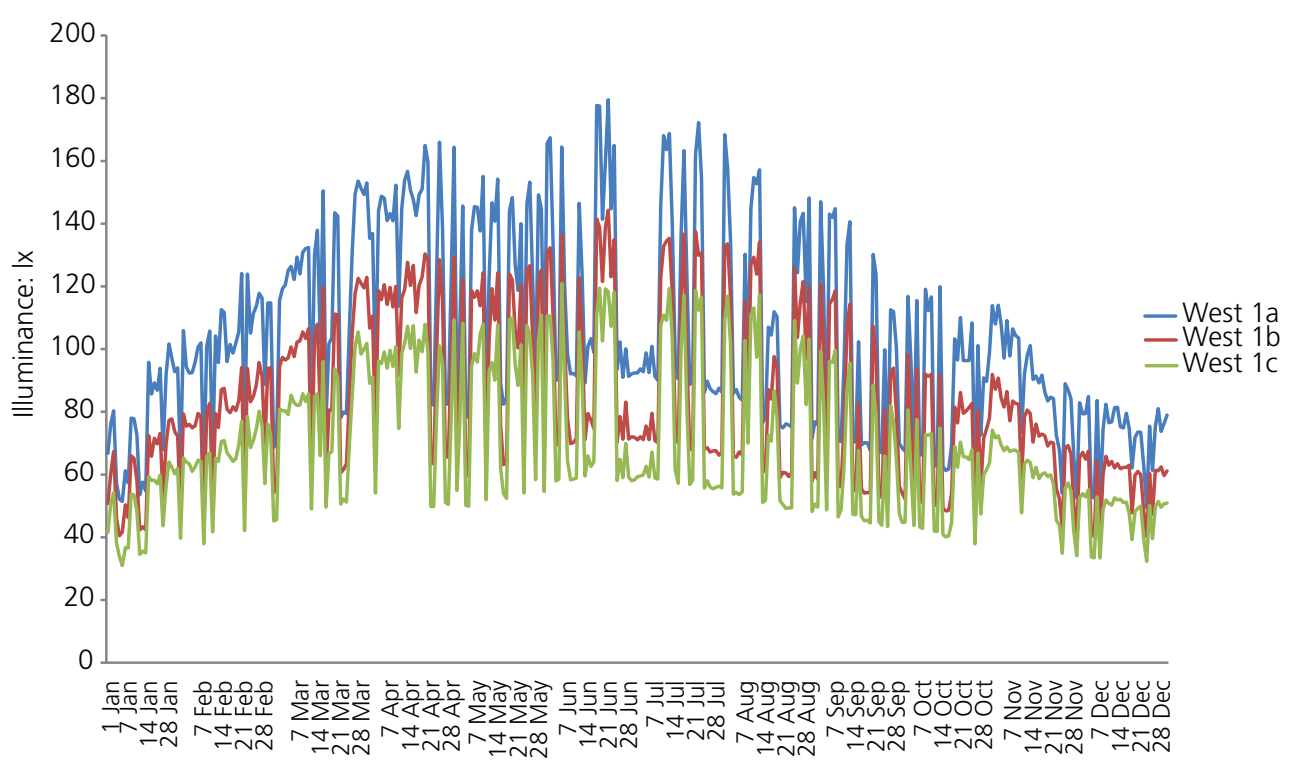

Figure 9. Average daily illuminance on the left-hand side of the western wall (reference points $1 \mathrm{a}, 1 \mathrm{~b}$ and $1 \mathrm{c}$ ) between 1 January and 31 December

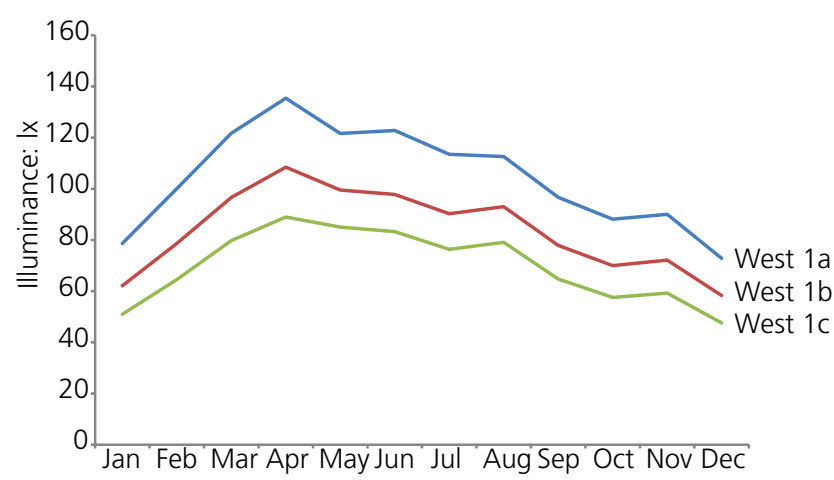

Figure 10. Average monthly illuminance on three sections of the left-hand side of the western wall

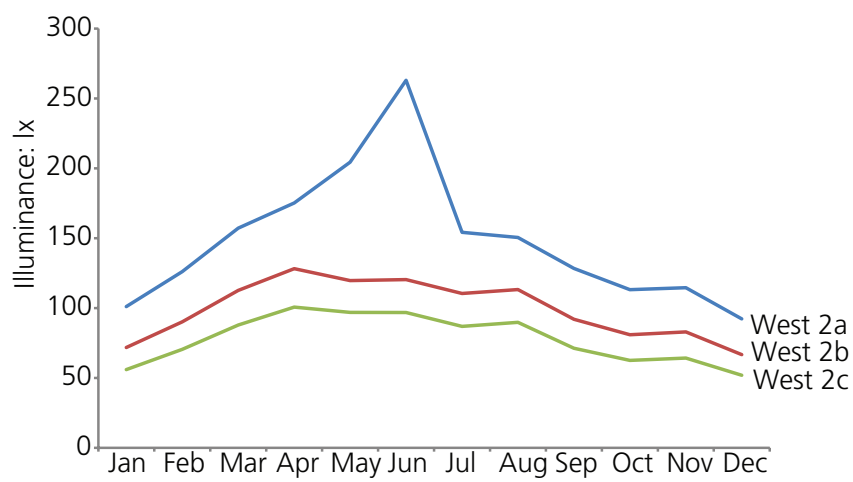

Figure 11. Average monthly illuminance on central section of the western wall 


\section{REFERENCES}

Al-Maiyah S and Elkadi H (2007) The role of daylight in preserving identities in heritage context. Renewable and Sustainable Energy Reviews 11(7): 1544-1557.

Al-Maiyah S and Elkadi H (2012) Study on the visual performance of a traditional residential neighborhood in old Cairo. Journal of Urban Technology 19(4): 59-86.

Al-Sallal K and Dalmouk M (2011) Indigenous buildings' use as museums: evaluation of day-lit spaces with the Dreesheh double panel window. Sustainable Cities and Society 1(2): 116-124.

Baker N and Steemers K (2002) Daylight Design of Buildings James \& James London, UK.

Balocco C and Frangioni E (2010) Natural lighting in the Hall of Two Hundred: a proposal for exhibition of its ancient tapestries. Journal of Cultural Heritage 11(1): 113-118.

BSI (2011) BS EN 12464-1: Light and lighting. Lighting of work places. BSI, London, UK.

Carver M (1994) Lighting design and energy efficiency in museums and galleries. In Museum Environment Energy: A Publication of the Museums \& Galleries Commission with the Support of the Energy Efficiency Office (Cassar M (ed.)). HMSO, London, UK.

Cengiz I (2012) Trace of an Empire: Osmangazi Osmangazi Municipality Istanbul, Turkey.

CIBSE (Chartered Institution of Building Services Engineers) (1994) Lighting for Museums and Art Galleries CIBSE London, UK.

de Hoyo-Meléndeza J, Mecklenburga $M$ and Doménech-Carbó $M$ (2011) An evaluation of daylight distribution as an initial preventive conservation measure at two Smithsonian Institution Museums, Washington DC, USA. Journal of Cultural Heritage 12(1): 54-64.

Erkin E, Manav B, Kutlu R and Küçükdoğu M (2009) Evaluation of the legal legislative framework for interior lighting during the integration process to the European Union. Proceedings of TMMOB (Union of Engineers and Architects of Turkey) Chamber of Electrical Engineers National Lighting Symposium, Izmir, Turkey, pp. 7-10.
Kensek K and Yong Suk J (2011) Daylight factor (overcast sky) versus daylight availability (clear sky) in computer-based daylighting simulations. Journal of Creative Sustainable Architecture \& Built Environment 1: 3-14.

Kim C and Chung S (2011) Daylighting simulation as an architectural design process in museums installed with toplights. Building and Environment 46(1): 210-222.

Lighting Design and Simulation Knowledgebase (2015) Lighting Design Glossary. See http://www.schorsch.com/en/kbase/ glossary/ (accessed 01/04/2014).

Mardaljevic J (2000) The simulation of annual daylighting profiles for internal illuminance. Lighting Research and Technology 32(3): 111-118.

Mardaljevic J (2006) Examples of climate-based daylight modelling. Proceedings of CIBSE National Conference Engineering for the Future. London, UK, pp. 21-22.

Mardaljevic J, Anderson M, Roy N and Christoffersen J (2011) Daylighting metrics for residential buildings. Proceedings of 27th session of the CIE. Sun City, South Africa, pp. 11-15.

Nelson L (2004) Architectural character: identifying the visual aspects of historic buildings as an aid to preserving their character. The Preservation of Historic Architecture - The U.S. Government's Official Guidelines for Preserving Historic Homes Lyons Press Guildford, CT, USA.

Rea MS (ed.) (2000) IESNA Lighting Handbook: Reference \& Application, 9th edn. Illuminating Engineering Society of North America New York, NY, USA.

Salam-Liebich H (1983) Khans and hammams. The Architecture of the Mamluk City of Tripoli Aga Khan Program for Islamic Architecture Cambridge, MA, USA.

Tzempelikos A and Athienitis AK (2005) Integrated daylighting and thermal analysis of office buildings. ASHRAE Transactions 111(1): 227-238.

US Dol (United States Department of the Interior) (1999) Museum Handbook National Park Service, US DoI Washington, DC, USA.

\section{WHAT DO YOU THINK?}

To discuss this paper, please submit up to 500 words to the editor at journals@ice.org.uk. Your contribution will be forwarded to the author(s) for a reply and, if considered appropriate by the editorial panel, will be published as a discussion in a future issue of the journal.

Proceedings journals rely entirely on contributions sent in by civil engineering professionals, academics and students. Papers should be 2000-5000 words long (briefing papers should be 1000-2000 words long), with adequate illustrations and references. You can submit your paper online via www.icevirtuallibrary.com/content/journals, where you will also find detailed author guidelines. 